\title{
The Clinical Value of Serum Anti-Cyclic Citrullinated Peptide Antibodies for Juvenile Idiopathic Arthritis
}

\author{
Serum Antisiklik Sitrüline Peptid Antikorlarının Jüvenil İdiyopatik Artrit \\ Açısından Klinik Değeri
}

\author{
Xiaolan HUANG, ${ }^{1}$ Zheng XU, ${ }^{1}$ Fengqi WU, ${ }^{2}$ Xiaodai CUI, ${ }^{1}$ Xiaofeng LI, ${ }^{3}$ Xianzi CONG, ${ }^{3}$ Jianglin ZHANG ${ }^{3}$ \\ ${ }^{1}$ Clinical Central Laboratory, Capital Institute of Pediatrics, Beijing, China; \\ ${ }^{2}$ Department of Rheumatology-Immunology, the Affiliated Children's Hospital of Capital Institute of Pediatrics, Beijing, China; \\ ${ }^{3}$ Department of Rheumatology, Hinese People's Liberation Army General Hospital, Beijing, China
}

\begin{abstract}
Objectives: This study aims to compare the levels of serum anti-cyclic citrullinated peptide (anti-CCP) antibodies in patients with juvenile idiopathic arthritis (JIA) and adult rheumatoid arthritis (RA) and to discuss the clinical value of these antibodies in the diagnosis of JIA.
\end{abstract}

Patients and methods: This study was performed at the Capital Institute of Pediatrics in Beijing between February 2009 and December 2009. The levels of serum anti-CCP antibodies in 72 patients with JIA (33 boys, 39 girls; mean age $7.6 \pm 3.9$ years; range 2 to 15.9 years), 65 patients with RA (14 boys, 51 girls; mean age $47 \pm 14.3$ years; range 17 to 75 years), and 22 healthy children (10 boys, 12 girls; mean age $14.1 \pm 0.4$ years; range 6.1 to 15.7 years) were measured using an enzyme-linked immunosorbent assay (ELISA). The obtained data along with the clinical data were analyzed.

Results: The anti-CCP antibody positive rates for the JIA and RA groups were $12.5 \%$ and $73.85 \%$, respectively, whereas the rate for the control group was $0 \%(p<0.001)$. The antiCCP antibody positive rates of the polyarticular, oligoarticular, and systemic JIA groups were $31.25 \%, 14.8 \%$ and $0 \%$, respectively $(p<0.001)$. The rheumatoid factor $(R F)$ positive rates, joint destruction rates, and mean disease courses of the positive and negative anti-CCP antibody groups were $66.7 \%$ versus $7.9 \%$ (chi-square $=118.778, p<0.001$ ), $33.3 \%$ versus $6.3 \%$ (chi-square $=124.778, p<0.001$ ), and 18.1 months versus 13.7 months $(t=0.606, p=0.546)$, respectively.

Conclusion: The anti-CCP antibody positive rate in patients with JIA is lower than for patients with RA. However this rate varies significantly according to the subtypes of JIA. Positive anti-CCP antibodies often indicate severe joint destruction.

Key words: Adult rheumatoid arthritis; anti-cyclic citrullinated peptide antibodies; juvenile idiopathic arthritis.
Amaç: Bu çalışmada jüvenil idiyopatik artrit (JIA) ve erişkin romatoid artrit (RA) hastalarında serum antisiklik sitrüline peptid (anti-CCP) antikor düzeyleri karşılaştırıldı ve bu antikorların JIA tanısındaki klinik değeri tartışıldı.

Hastalar ve yöntemler: Çalışma Beijing Pediatri Capital Enstitüsü'nde Şubat 2009 - Aralık 2009 tarihleri arasında yapıldı. Yetmiş iki JIA hastasında (33 erkek, 39 kız; ort.

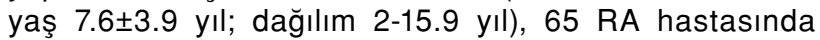
(14 erkek, 51 kız; ort. yaş $47 \pm 14.3$ yıl; dağılım 17-75 yıl) ve 22 sağlıklı çocuk hastada (10 erkek, 12 kız; ort. yaş $14.1 \pm 0.4 \mathrm{yıl}$; dağılım 6.1 to $15.7 \mathrm{yıl})$ serum anti-CCP antikor düzeyleri, enzim bağlı immünosorbent testi (ELISA) ile ölçüldü. Elde edilen veriler, klinik veriler ile birlikte analiz edildi.

Bulgular: Jüvenil idiyopatik artrit ve RA gruplarının antiCCP antikor pozitif oranları, sırasıyla \%12.5 ve \%73.85 iken, bu oran kontrol grubunda $\% 0$ idi $(p<0.001)$. Poliartiküler, oligoartiküler ve sistemik JIA gruplarının anti-CCP antikor pozitif oranı, sırasıyla \%31.25, $\% 14.8$ ve $\% 0$ idi $(p<0.001)$. Romatoid faktör $(R F)$ pozitif oranları, eklem tahribatı oranları ve pozitif ve negatif anti-CCP antikor gruplarının ortalama hastalık süresi, sırasıyla \%7.9'a kıyasla \%66.7 (ki-kare=118.778, p<0.001), \%6.3'e kıyasla \%33.3 (ki-kare=124.778, $\mathrm{p}<0.001$ ) ve 13.7 aya kıyasla 18.1 ay idi $(t=0.606, p=0.546)$.

Sonuç: Anti-CCP antikor pozitif oranı, JIA hastalarında, RA hastalarına kıyasla daha düşük olmakla birlikte, JıA'nın alt tiplerine göre büyük ölçüde değişiklik gösterir. Pozitif antiCCP antikorları, genellikle şiddetli eklem tahribatını gösterir. Anahtar sözcükler: Erişkin romatoid artrit; antisiklik sitrüline peptid antikorları; jüvenil idiyopatik artrit.

Received: February 21, 2012 Accepted: May 19, 2012

Correspondence: Xiaodai Cui, M.D. Clinical Central Laboratory, Capital Institute of Pediatrics, 100020 Beijing, China.

Tel: 86-010-85695548 e-mail: xiaodaicui@126.com

(92012 Turkish League Against Rheumatism. All rights reserved. 
Juvenile idiopathic arthritis (JIA) is a common systemic rheumatic disease among children. Its dominant feature is chronic synovitis accompanied by different degrees of involvement of other organs, but it does not affect bones and joints. Juvenile idiopathic arthritis is an autoimmune disease which causes the highest disability rate among children, yet its etiology still remains unknown. ${ }^{[1]}$ It can be classified into different subtypes, such as systemic JIA, polyarticular JIA, and oligoarticular JIA, according to its onset characteristics and early six-month course. ${ }^{[2]}$ Rheumatoid arthritis (RA) is one of the most common autoimmune diseases among adults, with an incidence rate of $1-2 \% \cdot{ }^{[3]}$ Although rheumatoid factor (RF) is one of the serological markers of RA, neither its sensitivity nor its specificity in diagnosis of JIA is high ${ }^{[4,5]}$ since its positive expression can only be detected by latex agglutination in $5-10 \%$ of children with JIA. For example, among children with polyarticular JIA, positive RF can only be detected in those with a late disease onset and in those whose joints are severely destructed. ${ }^{[2]}$ At present, the diagnosis of JIA primarily depends on the clinical and radiological manifestations of JIA due to the lack of a specific and sensitive serological marker. Anti-cyclic citrullinated peptide (anti-CCP) antibodies have only been recently discovered to have a diagnostic value for RA, with a specificity of $96-100 \%{ }^{[6]}$ and a sensitivity of $40-85 \% \cdot{ }^{[7,8]}$ However, their diagnostic value for JIA is still controversial. Some scholars have reported that their sensitivity in the diagnosis of JIA was $4.4-15 \%,{ }^{[9,10]}$ but others have determined that it was $16.7-30.0 \%,{ }^{[11,12]}$ or even as high as $58.5 \% \cdot{ }^{[13]}$ An early diagnosis of JIA along with drug intervention treatment that occurs as early as possible can better control the disease's progression, relieve joint destruction, and improve a patient's prognosis.

In our study, the serum anti-CCP antibodies in children with JIA and patients with RA were detected using enzyme-linked immunosorbent assays (ELISA), and these were then compared. This data combined with the clinical and radiological data were analyzed to explore the diagnostic value of anti-CCP antibodies for JIA.

\section{PATIENTS AND METHODS}

\section{Subjects}

The JIA group was comprised of children diagnosed with JIA at the Capital Institute of Pediatrics between February 2009 and December 2009. The RA group was made up of adults diagnosed with RA during the same period, and the control group was composed of healthy children who received physical examinations during this time period.

Juvenile idiopathic arthritis was diagnosed according to the classification system that was amended by the International League of Associations for Rheumatology (ILAR) in 2001, ${ }^{[2]}$ and RA was diagnosed according to the classification system developed by the American College of Rheumatology (ACR) in 1987. ${ }^{[14]}$

\section{Clinical and radiological data}

A total of 72 children (33 boys, 39 girls; mean age $7.6 \pm 3.9$ years; range 2 to 15.9 years) with JIA were involved in our study. Their courses of JIA ranged from six to 120 months. Among the children, 29 suffered from systemic JIA, 27 had oligoarticular JIA, and 16 had been diagnosed with polyarticular JIA. The RA group contained 65 patients (14 males and 51 females; mean age of $47 \pm 14.3$ years; range 17 to 75 years), and the control group featured 22 children (10 boys, 12 girls; mean age $14.1 \pm 0.4$ years; range 6.1 to 15.7 years) (Table 1 ).

In the RA group, the average disease course was 14.06 months (ranging from three to 120 months). Positive RF was detected in 11 of the patients, and imaging showed that joint involvement occurred in

\begin{tabular}{|c|c|c|c|}
\hline & Cases & Male to female ratio & Age \\
\hline & & & Mean \pm SD \\
\hline Juvenile idiopathic arthritis & 72 & $39: 33$ & $7.58 \pm 3.93$ \\
\hline Polyarticular & 16 & & \\
\hline Oligoarticular & 27 & & \\
\hline Systemic & 29 & & \\
\hline Rheumatoid arthritis & 65 & $14: 51$ & $47.38 \pm 14.28$ \\
\hline Control & 22 & $21: 10$ & $14.1 \pm 0.38$ \\
\hline
\end{tabular}


seven cases, including five with bone destruction and two with cervical joint dislocation.

\section{Blood sample collection}

Two milliliters of peripheral venous blood was extracted from the empty stomachs of the participants in the morning. After centrifugation, the serum was kept in a refrigerator at $-20^{\circ} \mathrm{C}$, and the samples were not thawed until analysis.

\section{Anti-CCP antibody detection}

The ELISA method was used to test the antiCCP antibodies, and the procedures were performed according to the instructions indicated in the kits that were utilized (Axis-Shield, Diagnostics Limited, Dundee, Scotland; Euroimmun, Lübeck, Germany; and Shanghai Fuchun Jianye (group) Limited Company, Shanghai, China). The results were obtained based on the standard curves for determination of positivity or negativity of the serum samples.

\section{Clinical data collection}

The clinical data of the patients with JIA, including the course of the disease, symptoms, vital signs, and laboratory examination indices such as RF and radiologic data, was carefully collected, Statistical analysis.

The data was analyzed using the Statistical Package for Social Sciences (SPSS Inc., Chicago, Illinois, USA) version 13.0 software program for Windows. Statistical descriptions were given to the measurement data, Student's t-test was used for comparisons between sample means, and a chi-square test was carried out for enumeration data. A $p$ value of $<0.05$ was considered statistically significant.

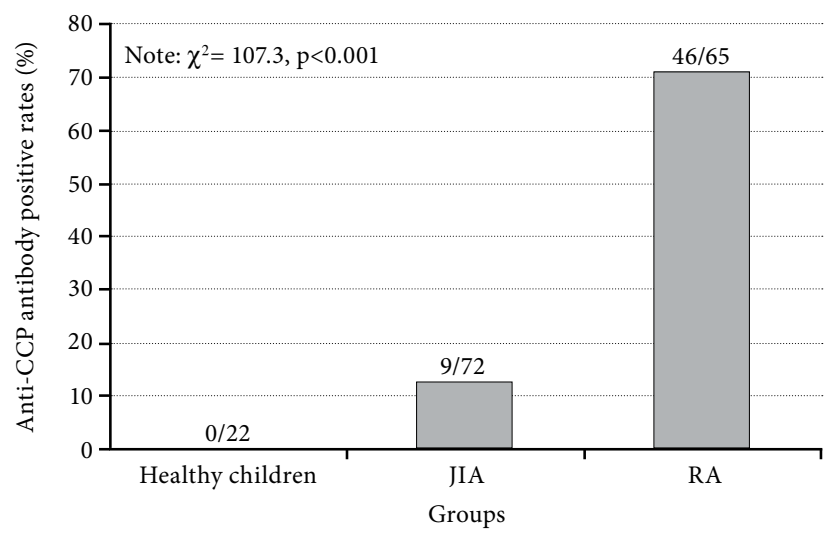

Figure 1. The positive anti-cyclic citrullinated peptide antibody rates of the control, juvenile idiopathic arthritis (JIA), and rheumatoid arthritis (RA) groups. CCP: Cyclic citrullinated peptide.

\section{RESULTS}

\section{Comparisons among different groups}

The anti-CCP antibodies in the different groups were detected using the Axis-Shield kit. The results showed that positive anti-CCP antibodies were detected in nine children with JIA (12.5\%) and 46 adults with RA (73.85\%), whereas no positive anti-CCP antibodies were detected in the control group. The chi-square test showed significant differences in the positive anti-CCP antibody rate among the three groups $(\mathrm{p}<0.001$; Figure 1).

\section{Comparisons among different JIA subgroups}

In the JIA group, positive anti-CCP antibodies were found in five children with polyarticular JIA (31.25\%) and four children with oligoarticular JIA (14.8\%), but no positive anti-CCP antibodies were found in the systemic group. The chi-square test showed that both the polyarticular group and the oligoarticular group had a significant difference in the positive antiCCP antibody rate compared with the systemic group $(\mathrm{p}<0.001$; Figure 2).

\section{Comparisons between the positive and negative anti-CCP antibody JIA groups}

Rheumatoid factor (RF), radiological changes, and disease courses were compared between the positive and negative anti-CCP antibody JIA groups (Table 2). Among the nine children with positive antiCCP antibodies, six were found to have positive RF, and three had joint lesions. Among the 63 children with negative anti-CCP antibodies, five were found to have positive RF, and four had joint lesions. These two groups showed significant differences in both the positive RF rate and joint lesions according to the

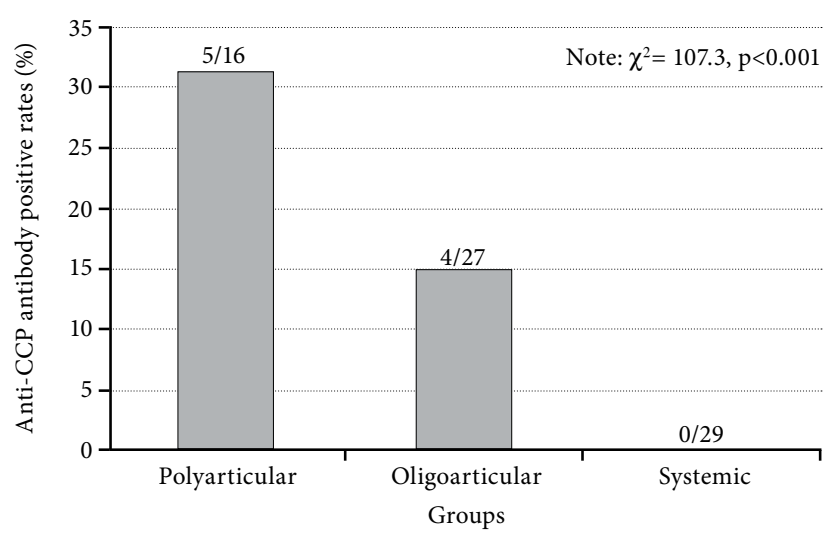

Figure 2. The positive anti-cyclic citrullinated peptide antibody rates of different juvenile idiopathic arthritis subtypes. CCP: Cyclic citrullinated peptide. 
Table 2. Comparisons between rheumatoid factor, radiological changes, and disease course in the positive and negative anti-cyclic citrullinated peptide antibody juvenile idiopathic arthritis groups

\begin{tabular}{|c|c|c|c|c|c|c|}
\hline & \multicolumn{2}{|c|}{ Positive JIA } & \multicolumn{2}{|c|}{ Negative JIA } & \multirow[t]{2}{*}{ Chi-square } & \multirow[b]{2}{*}{$p$} \\
\hline & $\mathrm{n}$ & $\%$ & $\mathrm{n}$ & $\%$ & & \\
\hline Rheumatoid factor positive rate & $6 / 9$ & 66.7 & $5 / 63$ & 7.9 & 118.778 & $<0.001$ \\
\hline Radiological changes & $3 / 9$ & 33.3 & $4 / 63$ & 6.3 & 124.778 & $<0.001$ \\
\hline Disease course (months) & 18.1 & & 13.7 & & $0.606^{*}$ & 0.546 \\
\hline
\end{tabular}

chi-square tests $(\mathrm{p}<0.001)$. However, no significant difference in the mean disease course was found between the two JIA groups.

\section{Comparisons in the polyarticular and oligoarticular JIA groups}

In both the polyarticular JIA group and the oligoarticular JIA group, disease courses were compared between children with positive and negative anti-CCP antibodies (Table 3). Among the 16 children with polyarticular JIA, five were identified with positive anti-CCP antibodies, and 11 were found to have negative anti-CCP antibodies. The mean disease course of the positive group was 13.2 months (ranging from 3 to 24 months) while it was 23.12 months (ranging from 3 days to 60 months) for the negative group. No significant difference was determined $(\mathrm{t}=-0.83, \mathrm{p}=0.42)$. Among the 27 children with oligoarticular JIA, four were found to have positive anti-CCP antibodies. The mean disease course of the positive group was 23.0 months (ranging from 7 to 60 months) while it was 12.7 months (ranging from 2 days to 48 months) for the negative group. Again, there was no significant difference $(t=1.21, p=0.47)$.

\section{Comparisons of the results obtained using different kits}

The results obtained using different kits were also compared (Table 4). The positive anti-CCP antibody rates did not show a significant difference when the chi-square test was applied $(\mathrm{p}=0.86)$, and the consistency test also showed no significant difference (Kappa $=0.884, \mathrm{p}=0.08)$.

\section{DISCUSSION}

Up to now, the factors that cause JIA and its pathogenesis still remain explored mystery. Juvenile idiopathic arthritis has clinical features which greatly differ from those of RA. ${ }^{[15,16]}$ It is also generally thought to be a heterogeneous disease that has close correlations with genetic predisposition, immunologic derangement, and environmental factors. Based on differences in

Table 3. Comparisons between the disease courses in both the polyarticular juvenile idiopathic arthritis group and the oligoarticular group

\begin{tabular}{lcccc}
\hline & $\begin{array}{c}\text { Disease course of the } \\
\text { positive group (months) }\end{array}$ & $\begin{array}{c}\text { Disease course of the } \\
\text { negative group (months) }\end{array}$ & t & $p$ \\
\hline Polyarticular & $14.20 \pm 9.93$ & $23.12 \pm 22.67$ & -0.83 & 0.42 \\
Oligoarticular & $23.00 \pm 24.80$ & $12.71 \pm 14.02$ & 1.21 & 0.47 \\
\hline
\end{tabular}

\begin{tabular}{|c|c|c|c|c|c|c|}
\hline & \multicolumn{2}{|c|}{ The positive rate } & \multirow[t]{2}{*}{ Chi-square } & \multirow[t]{2}{*}{$p$} & \multirow[t]{2}{*}{ Kappa } & \multirow[t]{2}{*}{$p$} \\
\hline & $\mathrm{n}$ & $\%$ & & & & \\
\hline \multicolumn{7}{|l|}{ Anti-CCP antibodies } \\
\hline Axis-shield & $9 / 72$ & 12.5 & & & & \\
\hline Shanghai Fuchun & $11 / 72$ & 15.3 & 0.301 & 0.86 & 0.884 & 0.08 \\
\hline Euroimmun & $11 / 72$ & 15.3 & & & & \\
\hline
\end{tabular}


onset features, clinical manifestations, disease courses, and outcomes, JIA can be classified into different subtypes such as systemic JIA, polyarticular JIA, and oligoarticular JIA. ${ }^{[17]}$ Juvenile idiopathic arthritis is an autoimmune disease which can lead to a high disability rate among children; therefore, early diagnosis and treatment are vital for the improvement of joint lesions and the prognosis of the patients.

However, since a highly specific and sensitive laboratory marker of JIA has not yet been found, diagnosis mainly depends on the clinical manifestations. Although RF has a high sensitivity in the diagnosis of RA (but with a low specificity), it has a low sensitivity in the diagnosis of JIA. ${ }^{[18]}$ Anti-cyclic citrillunated peptide antibodies have only been recently reported to have specific antibodies which reveal a diagnostic value for the diagnosis of RA. ${ }^{[19]}$ In the current study, the positive anti-CCP antibody rate in the JIA group was $12.5 \%$, which is basically consistent with a previous report by van Rossum et al., ${ }^{[10]}$ and the rate of the control group was $0 \%$. These results suggest that anti-CCP antibodies have a high specificity in the diagnosis of JIA (100\%). Among 65 patients with RA, 48 had positive anti-CCP antibodies, and the rate was $73.8 \%$, which falls between the previously reported rates of $40 \%$ and $85 \%$ seen in the literature. ${ }^{[7,8,20]}$ These results show that anti-CCP antibodies have a lower sensitivity to JIA than RA. Significant differences in distribution among patients with different subtypes of JIA have been determined via anti-CCP antibodies. In our study, the positive antiCCP antibody rates of the polyarticular, oligoarticular, and systemic JIA groups were $45.5 \%, 17.4 \%$ and $0 \%$, respectively. This suggests that they are of certain directive significance in JIA clinical typing.

In addition, in order to make sure that the results obtained from our experiment were stable, parallel detections were performed using three different types of kits, and no significant differences were detected among the positive rates of the experimental subjects. This suggests that ELISA is a stable and reliable method for serum anti-CCP antibody detection.

Furthermore, we also analyzed radiological data in our study, and the results showed that joint destruction in the positive anti-CCP antibody JIA group was more severe than that in the negative anti-CCP antibody JIA group. This suggests that anti-CCP antibody detection has an important role in the evaluation of the severity of joint destruction in patients with JIA and in the prognosis of the patients. In addition, the $\mathrm{RF}$ positive rate of the positive anti-CCP antibody group was noticeably higher than that of the negative group, suggesting that the combined detection of antiCCP antibodies and RF is helpful for increasing the sensitivity and specificity in the diagnosis of JIA. These results are consistent with previous studies, ${ }^{[21-23]}$ and their simultaneous presence may be an indication for earlier immunosuppressive treatment. ${ }^{[24]}$

No significant difference in disease course was found between the positive and negative anti-CCP patients in either the polyarticular group or the oligoarticular group, which seems to indicate that antiCCP antibodies cannot serve as a reliable serological marker in the early diagnosis of JIA. However, our study showed that positive anti-CCP antibodies were primarily found in children with polyarticular and oligoarticular JIA, which conveys the idea that anti-CCP antibody detection might be of clinical significance in JIA typing and the prognostic evaluation of patients.

\section{Declaration of conflicting interests}

The authors declared no conflicts of interest with respect to the authorship and/or publication of this article.

\section{Funding}

This study was supported by the $11^{\text {th }}$ Five-Year Plan of China (2008BAI59B02).

\section{REFERENCES}

1. Ravelli A, Martini A. Juvenile idiopathic arthritis. Lancet 2007;369:767-78.

2. Petty RE, Southwood TR, Manners P, Baum J, Glass DN, Goldenberg J, et al. International League of Associations for Rheumatology classification of juvenile idiopathic arthritis: second revision, Edmonton, 2001. J Rheumatol 2004;31:390-2.

3. Morrow J, Nelson JL, Watts R, Isenberg D. Rheumatoid arthritis. In: Morrow J, Nelson JL, Watts R, Isenberg D, editors. Autoimmune rheumatic disease. 2nd ed. New York: Oxford University Press; 1999. p. 104-46.

4. Bas S, Perneger TV, Kunzle E, Vischer TL. Comparative study of different enzyme immunoassays for measurement of IgM and IgA rheumatoid factors. Ann Rheum Dis 2002;61:505-10.

5. Saraux A, Berthelot JM, Devauchelle V, Bendaoud B, Chalès $G$, Le Henaff $C$, et al. Value of antibodies to citrulline-containing peptides for diagnosing early rheumatoid arthritis. J Rheumatol 2003;30:2535-9.

6. Rojas-Serrano J, Burgos-Vargas R, Pérez LL, García CG, Moctezuma F, Vázquez-Mellado J. Very recent onset arthritis: the value of initial rheumatologist evaluation and anti-cyclic citrullinated peptide antibodies in the diagnosis of rheumatoid arthritis. Clin Rheumatol 2009;28:1135-9. 
7. Schellekens GA, Visser H, de Jong BA, van den Hoogen FH, Hazes JM, Breedveld FC, et al. The diagnostic properties of rheumatoid arthritis antibodies recognizing a cyclic citrullinated peptide. Arthritis Rheum 2000;43:155-63.

8. Avcin T, Cimaz R, Falcini F, Zulian F, Martini G, Simonini $\mathrm{G}$, et al. Prevalence and clinical significance of anti-cyclic citrullinated peptide antibodies in juvenile idiopathic arthritis. Ann Rheum Dis 2002;61:608-11.

9. Brunner JK, Sitzmann FC. Anticyclic citrullinated peptide antibodies in juvenile idiopathic arthritis. Mod Rheumatol 2006;16:372-5.

10. van Rossum $M$, van Soesbergen $R$, de Kort $S$, ten Cate $R$, Zwinderman AH, de Jong B, et al. Anti-cyclic citrullinated peptide (anti-CCP) antibodies in children with juvenile idiopathic arthritis. J Rheumatol 2003;30:825-8.

11. Kang M, Wang HW, Cheng PX, Yin ZD, Li XO, Shi H, et al. The clinical significance of anti-cyclic citrullinated peptide antibodies in juvenile idiopathic arthritis. Chinese Journal of Practical Pediatrics 2006; 21:446-8.

12. Kong LH, Peng S. Significance of Hidden Rheumatoid Factor IgM, Anti-cyclic citrullinated peptide antibodies, antikeratin antibodies, combined test in diagnosis of juvenile idiopathic arthritis. Journal of Applied Clinical Pediatrics 2007;22:680-1.

13. Teng Q, Liu YG, He XH. Diagnostic significance of combined testing of anti-cyclic citrullinated peptide antibody and hidden rheumatoid factor immunoglobulin $\mathrm{M}$ in patients with juvenile rheumatoid arthritis. Journal of Applied Clinical Pediatrics 2004;19:845-7.

14. Arnett FC, Edworthy SM, Bloch DA, McShane DJ, Fries JF, Cooper NS, et al. The American Rheumatism Association 1987 revised criteria for the classification of rheumatoid arthritis. Arthritis Rheum 1988;31:315-24.

15. Petty RE, Southwood TR, Baum J, Bhettay E, Glass DN, Manners P, et al. Revision of the proposed classification criteria for juvenile idiopathic arthritis: Durban, 1997. J Rheumatol 1998;25:1991-4.
16. Schneider R, Passo MH. Juvenile rheumatoid arthritis. Rheum Dis Clin North Am 2002;28:503-30.

17. Ferucci ED, Majka DS, Parrish LA, Moroldo MB, Ryan $\mathrm{M}$, Passo $\mathrm{M}$, et al. Antibodies against cyclic citrullinated peptide are associated with HLA-DR4 in simplex and multiplex polyarticular-onset juvenile rheumatoid arthritis. Arthritis Rheum 2005;52:239-46.

18. Lawrence JM 3rd, Moore TL, Osborn TG, Nesher G, Madson KL, Kinsella MB. Autoantibody studies in juvenile rheumatoid arthritis. Semin Arthritis Rheum 1993;22:265-74.

19. van Venrooij WJ, Zendman AJ, Pruijn GJ. Autoantibodies to citrullinated antigens in (early) rheumatoid arthritis. Autoimmun Rev 2006;6:37-41.

20. Kroot EJ, de Jong BA, van Leeuwen MA, Swinkels $H$, van den Hoogen FH, van't Hof $\mathrm{M}$, et al. The prognostic value of anti-cyclic citrullinated peptide antibody in patients with recent-onset rheumatoid arthritis. Arthritis Rheum 2000;43:1831-5.

21. Kroot EJ, de Jong BA, van Leeuwen MA, Swinkels H, van den Hoogen $\mathrm{FH}$, van't Hof $\mathrm{M}$, et al. The prognostic value of anti-cyclic citrullinated peptide antibody in patients with recent-onset rheumatoid arthritis. Arthritis Rheum 2000;43:1831-5.

22. Visser H, le Cessie S, Vos K, Breedveld FC, Hazes JM. How to diagnose rheumatoid arthritis early: a prediction model for persistent (erosive) arthritis. Arthritis Rheum 2002;46:357-65.

23. van Jaarsveld $\mathrm{CH}$, ter Borg EJ, Jacobs JW, Schellekens GA, Gmelig-Meyling FH, van Booma-Frankfort C, et al. The prognostic value of the antiperinuclear factor, anti-citrullinated peptide antibodies and rheumatoid factor in early rheumatoid arthritis. Clin Exp Rheumatol 1999;17:689-97.

24. O'Dell JR. Treating rheumatoid arthritis early: a window of opportunity? Arthritis Rheum 2002;46:283-5. 